\title{
Explaining Ideal Teacher Competences in the Islamic Republic of Iran-Based on the Revolutionary Documentations of Its Education and Pedagogical System
}

\author{
Pooran Khorooshi ${ }^{1}$, Ahmad Reza Nasr Isfahany ${ }^{2}$, Sayed Ebrahim Mirshahjafari ${ }^{2} \&$ Nematollah Mosapour $^{3}$ \\ ${ }^{1}$ Faculty of Education and Psychology, Farhangian University, Isfahan, Iran \\ ${ }^{2}$ Faculty of Education and Psychology, University of Isfahan, Isfahan, Iran \\ ${ }^{2}$ Vice-Chancellor for Education at Central Organization of Farhangiyan University, Tehran, Iran \\ Correspondence: Ahmad Reza Nasr Isfahany, Faculty of Education and Psychology, University of Isfahan, \\ Isfahan, Iran. Tel: 91-3128-7504. E-mail: arnasr@edu.ui.ac.ir
}

Received: May 3, $2016 \quad$ Accepted: July 22, $2016 \quad$ Online Published: November 24, 2016

doi:10.5539/ies.v9n12p148 URL: http://dx.doi.org/10.5539/ies.v9n12p148

\begin{abstract}
The roles of teachers and schools are changing, and so are expectations about them. Teachers must educate in progressively multicultural classrooms, coordinate students with particular needs, utilize ICT for teaching viably, engage in evaluation and accountability processes, and involve parents in schools. In such, this study aimed to identify and introduce ideal teacher competences in the Islamic Republic of Iran based on the revolutionary documentations of its education and pedagogical system. To do so, 544 pages of the texts of these documentations were meticulously studied and analyzed by qualitative content analysis using the inductive method in creating categories. Then, 138 items representing ideal teacher competences in the Islamic Republic of Iran were extracted and categorized. The results of the research showed 5 main domains of competences - including knowledge, skill, attitude, action, and ethics - as well as their sub-qualifications and related components. This analysis facilitates codification of special criteria for recruiting efficient and effective personnel; planning, predicting and designing a curriculum based on teacher competences; and attracting the attention of experts and macro curriculum planners of universities responsible for teacher training.
\end{abstract}

Keywords: teacher competence, ideal teacher in Islamic Republic of Iran, revolutionary documentations, education and pedagogical system

\section{Introduction}

Education quality is a central theme in education systems, and various studies have been directed toward seeing how quality in training is accomplished. Grauwe and Varghese (2000) concentrate on the reading material as the key component for enhancing quality; yet in a percentage of the literature, teacher competence is singled out as the key element (Westera, 2001; Medley \& Shannon, 1994; Shulman, 1986). Meanwhile, other studies highlight the significance of the relationship between teacher competence and student performance, especially in a circumstance where numerous elements contribute to the insufficient performance of students (Kulshrestha \& Pandey, 2013).

Competence is normally associated with exceedingly proficient performance and there is an immediate connection in the field of instruction between a teacher's professional competence and student performance.

\subsection{Defining Competence}

A competence has been defined as 'a complex combination of knowledge, skills, understanding, values, attitudes and desire, causing effective and embodied actions, in a particular scope (Crick, 2008). According to this description, competence is obviously distinct from skill, which is the ability to do complicated acts with precision, adaptability and lack of difficulty.

'Competence' in an education system is theoretically defined as a cognitive structure that facilitates specific behaviors. From an operational point of view, competence seems to cover a broad range of higher-order skills and behaviors that represent the ability to deal with complex and unpredictable situations; this includes knowledge, skills, attitudes, metacognition, strategic thinking, and conscious and intentional decision making 
(Westera, 2001).

In Estonia, the term of competence is legally based on responsibilities, tasks, rights, and requirements. On the other hand, it is dependent on the knowledge that enables a person to apply it in a particular field for his success (Estonian Youth Work Strategy, 2006-2013).

Teaching is definitely much more than a 'task' and engages values or assumptions about education, learning and society; thus the concept of teacher competencies may differ in various national contexts. As Conway et al. (2009) indicate, subjects such as the competences needed by teachers, their development over time, verification and recording connect with wider discussions including: assumptions about learning; the goal of education; society's expectations of, and demands on, the teacher; available resources, priorities and political will; the status of the profession; perceived external or international pressures; traditions and culture within a country; and the broader societal context and environment in which teaching and teacher education take place (European commission, 2013).

\subsection{Discussion}

The concept of competence in teaching encircles the following features: tacit and explicit knowledge; cognitive and practical skills; and dispositions, which are motivation, beliefs, value orientations and emotions (Rychen \& Salganik, 2003). It allows teachers to meet complex needs, by mobilizing psychosocial resources in context, thereby expanding them in a consistent way. It enables the teacher to act professionally and appropriately in a situation (Koster \& Dengerink, 2008), and also empowers teachers to accept responsibility for tasks, achieve the desired outcome efficiently, and optimize resources and efforts. It can manifest as a certain level of achievement along a sequence.It is described as a dynamic combination of cognitive and meta-cognitive skills: knowing and understanding; knowing how to act, and knowing how to be (González \&Wagenaar, 2005); and the aggregate relevant knowledge, skills and attitudes that ensure the ability to operate productively in a particular area of activity or field (Toompea, 2011).

Regarding the features of an effective teacher, some studies provide a list of teacher professional characteristics including attitudes (commitment, confidence, trustworthiness, respect); reasoning (analytic and conceptual thinking); expectations (drive for improvement, information -seeking, initiative); and leadership (flexibility, accountability, passion for learning) (Anderson, 2004; Hay, 2000). There is also stress on the importance of an individual and collective sense of self-efficiency (Geijsel et al., 2009; Goddard, W. Hoy, \& A. Hoy, 2000). Overall, "teacher competences", which infer a more extensive perspective of teacher professionalism, can be said to consider the multi-faceted parts of the teacher on numerous levels-the person, the school, the nearby society, and professional networks.

Since the range and complexity of teaching competencies in the 21 st century is so wide, it is improbable that any individual would own them all, nor have developed them all to the same high quality. In consequence, attention undoubtedly must be paid on the competencies or characteristics of an education system or a teaching team (European commission, 2013).

Teaching competences are thus complex combinations of knowledge, skills, understanding, values and attitudes, leading to effective action in situation. Since teaching is much more than a task, and involves values or assumptions concerning education, learning and society, the concept of teacher competences may resonate differently in different national contexts.

\subsection{Literature}

The research entitled "Common European Principles for Teacher Competences and Qualification" classifies the dimensions of teacher competence in three dimensions-working with others; working with knowledge, technology and information; and working with and in society-and mentions the necessity of paying attention to them (European Commission DG [Departments (Directorates-General) and services] Education and Culture, 2005).

The outcome of the 2004 study, "The European Profile for Language Teacher Education", determined the required teacher competences in 27 competence descriptors of knowledge and understanding, strategies, skills and values. Important descriptors of educational competences, such as pedagogical technological content knowledge (PTCK) (Mishra \& Koehler, 2006), learning to learn, and reflexive and research skills are also highlighted. European values and attitudes are stressed as key requirements: paying attention to citizenship rights and duties in Europe; reflective attitudes; and promoting collaboration, networking and lifelong learning, as linked to transversal skills (Kelly \& Grenfell, 2004).

In order to determine the competencies that are required of a Southeast Asian teacher in the 21st century, the 
research entitled "Southeast Asian Ministers of Education Organization Regional Center for Educational Innovation and Technology" (SEAMEO INNOTECH) (2009) provided a range of competences of which teachers become aware, understand, and apply in their classroom. The major attributes of evaluating the credibility of a "competent teacher" in this study were pedagogical skills, student performance assessment skills, classroom management skills, and professional development skills (Anon, 2010).

The research entitled "Support to Basic Education Project (SBEP)" was conducted from 2002-2005, with consideration of five elements, including: Teacher training, quality of education, management and organization, non-formal education and communication. The results of the research entitled "Generic Teacher Competencies" included six main areas of competencies, 31 sub-competencies, and 233 performance indicators. The six main competencies were comprised of: Personal and professional values-professional development, knowing the students, learning and teaching process, monitoring and evaluation of learning and development, school-family and society relationships, and knowledge of curriculum and content (Anon, 2006).

Researchers have mentioned the necessity of paying attention to teacher competencies and codifying them in order to contribute to achieving targets of national education; to carry out more effective cooperation and sharing of information at the national level; to establish a structure for comparison of teacher qualifications; to try to establish consistent social expectations concerning status and quality of the teaching profession; to establish a clear, understandable and reliable source for professional development of teachers; to reach a consensus at the national level regarding terminology and definitions to be used for discussions on the teaching profession; to define knowledge, skills, attitudes and values of teachers; and to try to raise teachers' status in the eyes of society by creating awareness, creating opportunities for students to "learn how to learn", and ensuring the quality of professional teaching for a society.

In Iran, codifying and publication of strategic documentations of the education system, which has been codified and passed by law in recent years, includes "theoretical foundations of fundamental transformation in the general-official education system of [the] Islamic Republic of Iran" (Ministry of Education, 2011); "National curriculum of [the] Islamic Republic of Iran" (Ministry of Education, 2012); and "Document of fundamental transformation of education" (Ministry of Education, 2011).

In the studies, three classifications of problems in the country's public and official education system have been proposed: 1) The lack of adjusting and organizing the local and codified educational philosophical framework fitted to Iran's Islamic society in designing policies and activities for training individuals in the society; 2) The lack of a codified philosophy fitted to Iranian and Islamic standards of the present, official and public education system in order to determine features, goals, aims, and principles governing this kind of education. Also to be determined are its relationship with other factors contributing to, and effective in, education such as government, family, media, and the higher education system; and 3)Organizing and developing the present official and public education system without considering a comprehensive theoretical model with Islamic and Iranian features (Ministry of Education, 2011, pp. 22-23).

In Islamic education, humanity is the most important creature God created and human training is the most important issue in the world. Any event that is about to happen in the world is the consequence of the events that happen to humanity and inside them. In the holy Koran, God states that any external event is the consequence of humans' change and humans' coming to a conclusion (rad: 11).

According to the Islamic worldview, training is "an interactive process laying the ground for continuous evolution and sublimation of the trainees' identity in an integrated coherent manner and based on [the] Islamic system's criterion for humans' guidance on the way of preparing for conscious and voluntary realization of the stages of pure life in all its dimensions (Ministry of Education, 2011: 139). In this definition, trainers are "a group of rather developed, sympathetic, and benevolent individuals who have taken the heavy responsibility of helping with others' guidance, and laying the ground for trainees' growth and essence revolution in line with constant formation and progress of a righteous and virtuous society due to their attainment of individual and collective competencies and a remarkable realization of pure life" (Ministry of Education, 2011, p. 137).

\subsection{Hypothesis}

Therefore, the main question of this research is what competencies teachers should develop themselves in order to lay the groundwork for these same competencies in their trainees? The foundation for finding the answer to this question in the present research is searching for, and identifying, teachers' qualifications and competences, which are mentioned in three transformational documentations. These are: "The theoretical foundations of fundamental transformation in the general education system of [the] Islamic Republic of Iran", "National curriculum of [the] Islamic Republic of Iran", and "Document of fundamental transformation of education". 


\section{Method}

The present research is a qualitative study using the inductive method in creating categories, as proposed by Mayring (2000). Inductive stages of qualitative analysis include precise determination of the text's methodological categories. The purpose is to provide a clear definition of samples and coding principles related to the categories through which it is determined the circumstances that are coded and defined. Definitions related to categories can be used in the process of coding (Maroofi \& Yusefzade, 2010, p. 97). In the present research, the documents in Table 1 were studied.

Table 1. The studied transformational documents of the education and pedagogical system in Iran

\begin{tabular}{llll}
\hline Row & Document & Code & Number of Pages \\
\hline 1 & Theoretical foundations of the fundamental transformation of education & 1 & 450 \\
2 & Document of fundamental transformation of education & 2 & 26 \\
3 & National curriculum of the Islamic Republic of Iran & 3 & 68 \\
\hline Total & & 544 \\
\hline
\end{tabular}

\subsection{Sampling}

In this study, items, phrases, and sentences related to teacher competences were extracted from the content of documents without any change or omission of subject matter. In the end, 286 items that were independent of texts of documents were obtained. On one hand, they were directly related to teacher competencies, and on the other hand, they were related to other factors causing them. For the same reason, all statements in the texts of documents that were related to teacher competencies were coded into the categories understood from the messages they conveyed, merged, and classified. To do so, items were categorized in terms of content in a range from macro and qualitative subject matter to descriptive, quantitative subject matter. In other words, main categories and minor categories of teacher competencies and factors causing them were coded, merged, and categorized. Regarding the main purpose of this research, only results related to the main categories of teacher competencies are offered in this article.

\subsection{Validity}

For investigating validity, concepts and categories were studied several times and were readjusted. In addition, based on the criteria proposed by Creswell and Miller (2000) for ensuring research validity, the report of the first stage of the analysis process and its obtained categories was given to three faculty members of the university and one specialist in the field of academic curriculum. After revision, their recommendations were implemented in the first stage of coding. Then, the same individuals studied the final coding in the next stage and their opinions were implemented in the final codification.

\section{Results}

Out of all 286 items related to teacher competencies and their causes, 138 items (48/3\%) were identified as teacher competencies' items categorized into 5 main classifications - knowledge, skill, attitude, practice, and ethic — and an example of each classification was given (Table 2).

Table 2. Categories related to teacher competencies derived from three documents of education and pedagogy in Iran

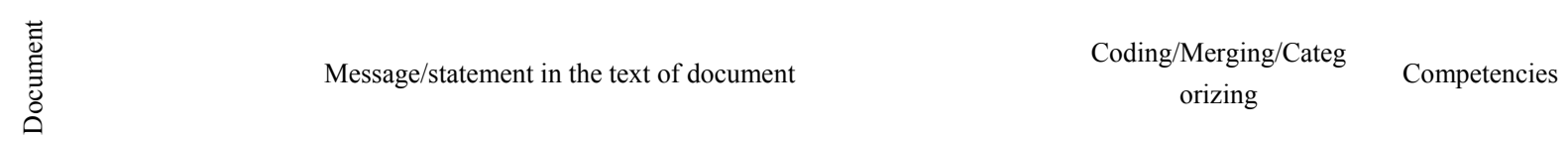

1 1.1.1.Acquiring individual and collective competences

1.1.2.Understanding and acquiring necessary qualifications for new- comers

1.1.Acquiring
knowledge,
$\begin{aligned} & \text { recognition } \\ & \text { awareness }\end{aligned}$ and 1. Knowledge




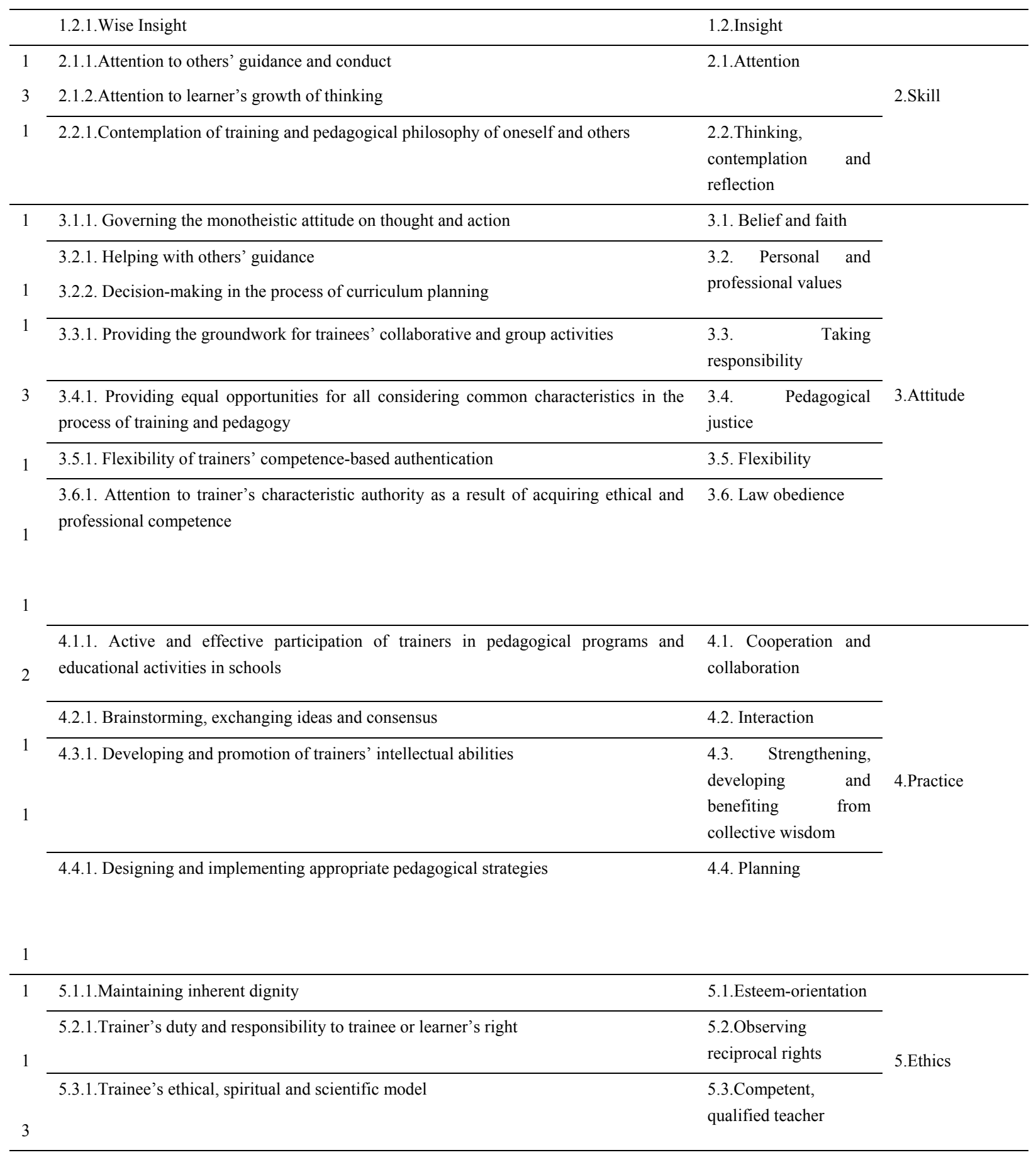

The lowest frequency identified in teacher competences in the content of the documents on Iran's educational and pedagogical system in the five main classifications was related to knowledge, while the highest frequency was related to attitude (Table 3).

Table 3. Frequency and percentage of categories related to teacher competencies taken from Iran's educational system documents

\begin{tabular}{lcc}
\hline Competencies & Frequency & Percentage \\
\hline 1-Attitude & 54 & 39 \\
2-Practice & 42 & 30.5 \\
\hline
\end{tabular}




\begin{tabular}{lcc}
\hline 3-Ethics & 18 & 13 \\
4-Skill & 15 & 11 \\
5-Knowledge & 9 & 6.5
\end{tabular}

Overall, independent items include 109 competencies (79\%) related to the theoretical foundations of fundamental transformation in education system; three competencies $(2 / 2 \%)$ related to the fundamental transformation document; and 26 competencies (18.8\%) related to the national curriculum document. In general, they make 138 competencies, as shown in Table 4 . The highest frequency of teacher competences is in document No.1 and the lowest is in document No.2. Regarding the point that document No.1 is qualitatively and quantitatively more comprehensive and deals with fundamental issues more than the other two documents, it seems that the quantitative difference of teacher competencies' frequency is natural in comparison with other documents in the mentioned dimensions.

Table 4. Frequency of teacher competencies extracted from the documents of the educational system in Iran

\begin{tabular}{|c|c|c|c|c|}
\hline Competencies & $\begin{array}{c}\text { 1-Theoretical foundations of } \\
\text { fundamental transformation } \\
\text { of education }\end{array}$ & $\begin{array}{c}\text { 2-National curriculum } \\
\text { of the Islamic Republic } \\
\text { of Iran }\end{array}$ & $\begin{array}{l}\text { 3-Document of } \\
\text { fundamental } \\
\text { transformation of } \\
\text { education }\end{array}$ & Total \\
\hline 1-Attitude & 40 & 2 & 12 & 54 \\
\hline 2-Practice & 34 & 1 & 7 & 42 \\
\hline 3-Ethics & 16 & - & 2 & 18 \\
\hline 4-Skill & 10 & - & 5 & 15 \\
\hline 5-Knowledge & 9 & - & - & 9 \\
\hline Total & 109 & 3 & 26 & 138 \\
\hline Percentage & 79 & 2.2 & 18.8 & 100 \\
\hline
\end{tabular}

\section{Discussion}

In general, based on the results, the main category, i.e., teacher competencies, was studied as the center of the process and the minor categories were around it, with the sub-categories related to them also circling. The conceptual framework explaining teacher competencies along with their sub-competencies and their related elements extracted from Iran's educational system's documents are shown in Figure 1.

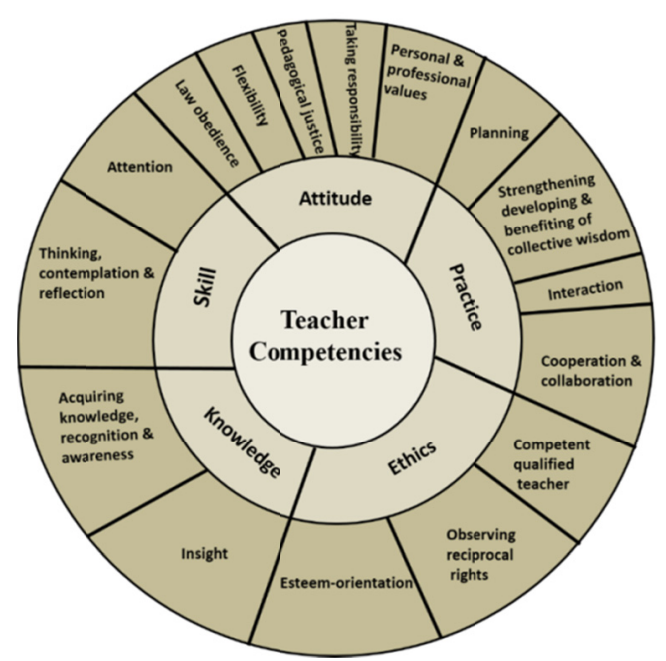

Figure 1. The conceptual framework explaining a teacher's competencies in transformational documents of the educational system in Iran (based on the inductive method in creating categories) 
The aim of the present study was explaining a general picture of teacher competencies in transformational documents of the educational system in the country. The items in the documents, from general to peripheral issues, were categorized in five main dimensions of knowledge, skill, attitude, practice, and ethics. The main issue, teacher competencies, was at the center of the model and peripheral issues were around it. In such, the model represents the relationship between different dimensions of competencies in the documents of the educational system of the country.

The findings were in agreement with the findings of Koster and Dengerink (2008), who stated that competencies are a combination of knowledge, skills, attitudes, values, and personal features that enable a teacher to act professionally and adequately in a situation. The findings are also in line with the research done on the education ministry in Turkey (2006), which pointed out that teachers' competencies represents knowledge, skills, and attitudes required for effective and efficient professional teaching. However, in the present study, the other two dimensions of competencies - practice and ethics - were found.

The important point drawn from the research is that in transformational documents, only two groups of basic competencies (beliefs and ethics, and basic knowledge), and particular competencies (content knowledge, pedagogical knowledge, and pedagogical skills) are mentioned for deepening teachers' common and professional identity in individual, humanistic, Islamic, and Iranian dimensions (Ministry of education, 2011, p.138). Nevertheless, they are only in the form of macro-statements. A list of competences, their related standards, or how to achieve them is not mentioned.

Considering the most important feature of pedagogy, which according to its definition in the fundamental transformation document is reliance on elements and their components within an Islamic system, the best criterion for the acquisition of teachers' individual and collective competencies is reliance on an Islamic-based criterion. It is stated in the holy Quran that if there is anyone, male or female, who does good deeds and is a believer, we will certainly keep him/her alive with "pure life", and we will certainly reward them for the best thing they have done (Nahl: 97).

Since the ultimate goal of Islamic education is to achieve pure life - and the realization of pure life depends on the emergence of ethical values, attitudes, knowledge, and skills necessary - it must be considered that the intermediate objectives of education and pedagogy are a general framework to determine the content of education and training in teacher education curriculum.

Universities and institutions of higher education, as the cradles of teachers' education, focus on training; empowerment; promotion of general, special and professional competencies in accordance with Islamic values; and principles and needs of society. Their main task is to train and educate top specialists in the Islamic Republic of Iran. Therefore, they can have a clear, understandable, and reliable source at their disposal for professional development of teachers and reach a consensus at the national level by statutory regulation of a comprehensive set of competency standards. Due to the point that the aim of pedagogy is the realization of reality in oneself and preparation for acquiring competence to reach levels of pure life, teacher education programs in teacher training universities throughout Iran can take into consideration, and encompass all different aspects of, the growth of teachers' professional competence in the areas of ethics, skill, attitude, practice and knowledge.

\section{Conclusion}

Considering the role of teachers in schools, as major factors in the educational system, their ability and competence has a direct impact on the performance of formal education, and the competence of teachers is one of the most important issues in their career. Thus, recognizing their competence and its dimensions is a key factor for their development and evaluation. In addition, to avoid wasting energy, forces, capital, and scientific development in the country - and for displaying optimum and favorable situations in teacher education system-it is better to recognize and identify required qualifications and competencies; provide a model of these competencies to teachers; consider criteria for the selection of qualified individuals; and select these criteria in such a way that they are measurable in education.

On the other hand, due to the fact that in every society, the ultimate goal of teacher education is providing opportunities for teachers to gain knowledge, skills, abilities, attitudes, beliefs, and values within the framework of their competencies, curriculum in teacher education and its integration with the needs of society calls for special attention. It must help them with their efficiency and effectiveness-both for themselves and society — and this growth must be reflected in the teacher education curriculum; therefore, such a program could provide the grounds for teachers' sense of belonging and active participation in their professional and especial duties. If teachers could be trained by using a curriculum designed and planned for their competencies, and the grounds for the curriculum's reinforcement and development is provided, they will be able to use these features 
more effectively in students' learning process, considering that the revision of the structure of teacher education curriculum and paying attention to both monitoring and evaluation are its prerequisites.

The findings of this research offer several suggestions for further studies. First, since the policies governing the recruitment and pedagogy of human resources required for education-especially the education of teachers - should provide the possibility of selecting individuals who have desirable traits and habits, mental and physical abilities, and a high level of knowledge and professional skills, this study provides the grounds for the attention and awareness of teacher education curriculum planners, as well as experts responsible for absorbing and training human resources needed by universities and the educational system, and regulating teacher competence criteria.

Additionally, this study provides a conceptual framework by analyzing documents that can be used to prepare a competency-based curriculum. This framework is based on identifying and explaining the contents stated in the documents, so it pinpoints the necessity of paying attention to additional and complementary cases of all major and minor categories.

Furthermore, due to the point that an integrated, coherent curriculum for teacher education in the country is not predicted so far, this study provides a resource in designing a large-scale program for teacher education to develop and codify a teacher's competency-based curriculum. At the same time, it is necessary to conduct comparative studies with the curricula of teacher education in countries that are successful in the field of teacher competencies, since using successful experiences of other countries provides a platform to improve the process in Iran.

\section{References}

Anderson, L. W. (2004). Increasing teacher effectiveness (2nd ed.). Paris: UNESCO, IIEP.

Anon. (2006). Generic teacher competencies. Ankara: Turkish Republic Ministry of National Education General Directorate of Teacher Training.

Anon. (2010). Teaching competency standards in Southeast Asian Countries: Eleven country audit. Philippine Copyright: SEAMEO INNOTECH. Retrieved from http://www.seameo-innotech.org

Boyatzis, R. E. (1982). The competent manager: A model for effective Performance. New York: Wiley.

Conway, P. F., Murphy, R., Rath, A., \& Hall, K. (2009). Learning to Teach and its Implications for the Continuum of Teacher Education: A Nine-Country Cross-National Study. Report Commissioned by the Teaching Council. University College Cork and Teaching Council of Ireland.

Creswell, J. W., \& Miller, D. L. (2000). Determining validity in qualitative inquiry. Theoryinto practice, 39(3), 124-130. https://doi.org/10.1207/s15430421tip3903_2

Deakin, C. R. (2008). Pedagogy for citizenship. In F. Oser, \& W. Veugelers (Eds.), Gettinginvolved: Global citizenship development and sources of moral values (pp. 31-55). Rotterdam: Sense Publishers.

Dubois, D. D. (1993). Competency-based Performance improvement: A strategy for organizational change. Amherst, MA: HRD Press, Inc.

Estonian Youth Work Strategy. (2006-2013). Retrieved http://www.hm.ee/index.php?03240

European Commission DG Education and Culture. (2005). Common European Principles for teacher competences and qualifications. Brussels. http://ec.europa.eu/education/policies/2010/doc/principles_en.pdf

European commission, education and training. (2013). Supporting teacher competence development for better learning outcomes. http://ec.europa.eu/education/school-education/teacher-cluster_en.htm

Fogg, C. D. (1999). Implementing your strategic plan: How to turn "intent" into effective action for sustainable change. New York: American Management Association.

Geijsel, F., Sleegers, P., Stoel, R., \& Krüger, M. (2009). The effect of teacher psychological, school organizational and leadership factors on teachers' professional learning in dutch schools. The Elementary School Journal, 109(4), 406-427. https://doi.org/10.1086/593940

Goddard, R. D., Hoy, W. K., \& Hoy, A.W. (2000). Collective teacher efficacy: Its meaning, measure, and impact on student achievement. American Educational Research Journal, 37, 479-507. https://doi.org/10.3102/00028312037002479

González, J., \& Wagenaar, R. (Eds.) (2005). Tuning educational structures in Europe II. Universities' contribution to the Bologna Process. University of Deusto \& University of Groningen. 
Grauwe, A. D., \& Varghese, N. V. (2000). Improving school efficiency issues and priorities seminar report. In improving school efficiency: the Asia experience. Paris: international institute for educational planningUNESCO.

Hay, M. (2000). Research into teacher effectiveness: A model of teacher effectiveness. Research report No. 216. Norwich: The Crown Copyright Unit.

Kelly, M., \& Grenfell, M. (2004). European profile for language teacher education. A Frame of Reference. University of Southampton, UK.

Koster, B., \& Dengerink, J. J. (2008). Professional standards for teacher educators: how to deal with complexity, ownership and function. Experiences from the Netherlands. European Journal of Teacher Education, 31(2), 135-149. https://doi.org/10.1080/02619760802000115

Kulshrestha, A. K., \& Pandey, K. (2013). Teachers Training and Professional Competencies. Voice of Research, 1(4), 29-33.

Lucia, A. D., \& Lepsinger, R. (1999). The art and science of competency models: Pinpointing critical success factors in organizations. New York: Pfeiffer.

Maroofi, Y., \& Yusefzade, M. (2010). Content Analysis in human sciences. Iran: hamedam: Sepehr danesh. [Persian].

Mayring, P. (2000). Qualitative Content Analysis. Journal of Qualitative Social Research, 1(2), 202-212.

Medley, D. M., \& Shannon, D. M. (1994). Teacher evaluation. In T. Husén, \& T. N. Postlethwaite (Eds.), The International Encyclopedia of Education (2nd ed., Vol. X). Oxford: Pergamon.

Ministry of Education. (2011). Document fundamental transformation of education. Iran: Ministry of education, supreme council of the Cultural Revolution \& supreme Council of Education [Persian].

Ministry of Education. (2011). Theoretical foundations of fundamental transformation in the general education system of the Islamic Republic of Iran. Iran: Ministry of education, supreme council of the Cultural Revolution\& supreme Council of Education. [Persian]

Ministry of education. (2012). National curriculum. Iran: Ministry of education, supreme council of the Cultural Revolution\& supreme council of education. [Persian]

Mishra, P., \& Koehler, M. J. (2006). Technological pedagogical content knowledge: Aframework for teacher knowledge. Teachers college record, 108(6), 1017-1054. https://doi.org/10.1111/j.1467-9620.2006.00684.x

Rychen, D. S., \& Salganik, L. H. (2003). Key competencies for a successful life and a well-functioning society. Göttingen: Hogrefe \& Huber.

Shulman, L. S. (1986). Those who understand: knowledge growth in teaching. Educational Researcher, 15(2), 4-14. https://doi.org/10.3102/0013189X015002004

Toompea, T. (2011). National curriculum for upper secondary schools. Retrieved from www.ibe.unesco.org/curricula/estonia/er_usfw_2011_eng.pdf

Westera, W. (2001). Competences in education: A confusion of tongues. Curriculum Studies, 33(1), 75-88. https://doi.org/10.1080/00220270120625

\section{Copyrights}

Copyright for this article is retained by the author(s), with first publication rights granted to the journal.

This is an open-access article distributed under the terms and conditions of the Creative Commons Attribution license (http://creativecommons.org/licenses/by/4.0/). 